\title{
A Re-examination of the Sarcophagus Inscription at Turant Asarı
}

\author{
Turant Asarı'ndaki Mezar Yazıtı Üzerine Yeni Bir Ínceleme
}

\begin{abstract}
Mehmet ALKAN*
Abstract: In this article, a published sarcophagus inscription from Turant Asarı located $5 \mathrm{~km}$ northeast of Myra is re-examined and given a new reading. The era in the first line of the inscription and some personal names in other lines could not be precisely read in the first edition and these issues were then left

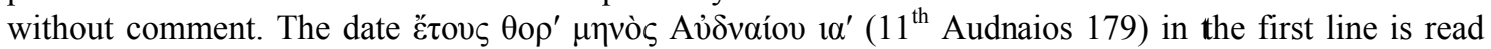
clearly. This date must have not been reckoned from $311 \mathrm{BC}$ according to the Seleucid era as the year 179 corresponds to $133 / 32 \mathrm{BC}$ which is too early for the epigraphic form of the letters in this inscription. It may be the Sullan era $(179=$ AD 94/5). But to date the inscription to the period after AD 43 seems doubtful from the kitharephoroi specified as the currency of penalty payment in the inscription. The typology of the sarcophagus and the letters characteristics of the inscription indicate a date around the end of first century $\mathrm{BC}$ or the beginning of first century $\mathrm{AD}$ and do not permit consideration of an era later than that of Sulla. This approximately dating is taken into consideration the year 179 goes back to the first half of the second century BC. The most important year in this period is $168 / 7 \mathrm{BC}$ with the independence of Lycia from Rhodian dominion that would mark the beginning of the Lycian era. In consequence, this article suggests the date recorded on this inscription was probably calculated from 168/7 BC (AD 11/12), the beginning of a new local era in Lycia. In the inscription two new personal names are deciphered as a

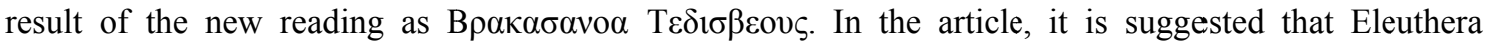
mentioned in the inscription should be Eleuthera Trebendatike. In previous editions the missing name and

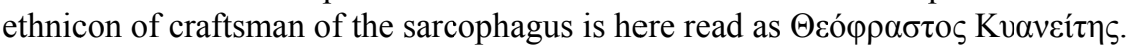

Keywords: Turant Asarı, era, Tedisbes, Brakasanoa, kitharephoroi, Eleuthera

Özet: Bu makalede, Myra'nın 5 km kuzeydoğusunda yer alan Turant Asarı'ndan yayınlı bir mezar yazıtı yeni okumalarla birlikte incelenmektedir. Yazıtın ilk satırındaki era tarihlemesi ve diğer satırlardaki bazı şahıs isimleri Schweyer tarafından yapılan ilk yayında tam olarak okunamamış ve bu hususlar yorumsuz

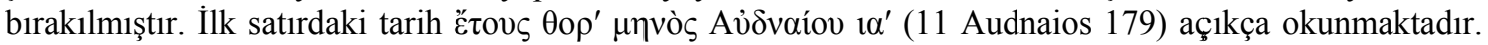
Bu tarih Seleukos era'sına göre İÖ. 311 yılından itibaren hesaplanmış olamaz. Çünkü 179 yılının tekabül ettiği İÖ. 133/32 yılı yazıtın harf özelliğine göre çok erkendir. Burada Sulla era'sının kullanılmış olması da (179=İS. 94/5) zayıf bir ihtimaldir. Zira ceza ödemesinin kitharephoroi para birimi üzerinden yapılacağı belirtildiği için yazıtı İS. 43 yılından sonraya tarihlemek kuşkulu görünmektedir. Lahit hem tipolojik özellikleri hem de yazıtın harf karakteri temelinde İÖ. I. yüzyılın sonu ile İS. I. yüzyılın başı civarına tarihlendirilmektedir. Bu durumda 179 yılı İÖ. II. yüzyılın ilk yarısına geri gider. Bu dönemde era başlangıcı olabilecek en önemli olay, Lykia'nın İ̈. 168/7 yılında Rhodos egemenliğinden kurtulmasıdır. Sonuç olarak makale, yazıttaki tarihin Lykia'da yeni bir era başlangıcı olarak İÖ. 168/7 yılından itibaren hesaplanmış olması ve yazıtın İS. 11/12 yılına tarihlenmesi gerektiğini önermektedir. Yeni


Yazıtta adı geçen Eleuthera'nın, Eleuthera Trebendatike olması gerektiği önerilmektedir. İlk yayında lahdi

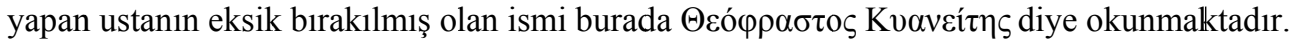

Anahtar Sözcükler: Turant Asarı, era, Tedisbes, Brakasanoa, kitharephoroi, Eleuthera

\footnotetext{
* MA., Akdeniz Üniversitesi, Edebiyat Fakültesi, Eskiçağ Dilleri ve Kültürleri Bölümü, Antalya, mehmedalkan@hotmail.com
} 
Turant Asarı is located on the top of Turant Dağ rising from the south of the Alakilise valley about $5 \mathrm{~km}$ northeast of the metropolis of Myra. The settlement established on this mount and an inscribed sarcophagus were first introduced by Harrison (1979, 205; see also Mellink, 1979, 344). The researcher briefly mentioned the content of this inscription without providing the text. Then, Schweyer used the inscription in her works, giving its transcription and photographs (Schweyer, 1993, 41-42, Taf. II Abb. 3 and Schweyer, 2002, 269 no. 89, Fig. 47, 48). The first line of the inscription consists of an era dating. The era dating and some personal names in other lines could not be completely read by Schweyer and these issues were left unresolved and without comment. However, the inscription is literally legible and requires re-examination hence this article.

The inscribed sarcophagus with hyposorion is one of some sarcophagi standing among the dozens of broken tombs in the extensive Roman necropolis in the settlement area (Harrison, 1979, 205; Mellink, 1979, 344; Schweyer 1996, 58; Harrison, 2001, 27-30; Hellenkemper \& Hild, 2004, 898 s.v. Turant Asarı).

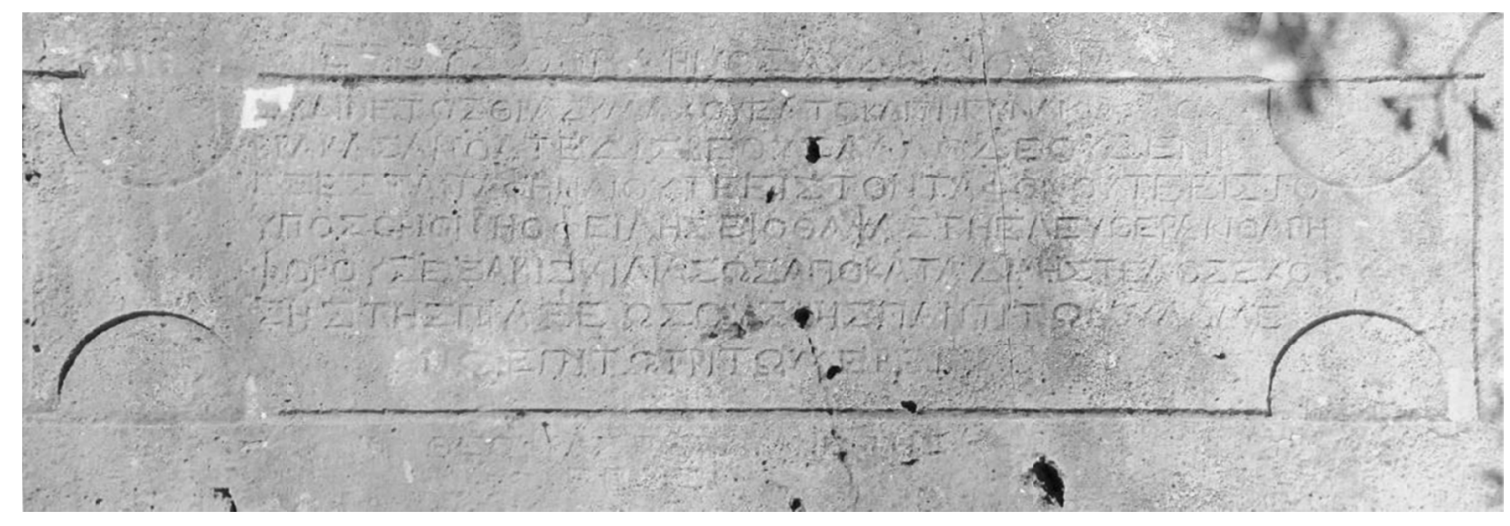

The dimensions of the sarcophagus measure; L.: $270 \mathrm{~cm}, \mathrm{~W} .: 155 \mathrm{~cm}, \mathrm{H} .: 190 \mathrm{~cm}$ and the lid H.: $150 \mathrm{~cm}$. The measurement of the tabula ansata; H.: $40 \mathrm{~cm}$; W.: $167 \mathrm{~cm}$ and the letter H.: 2,5-3 cm. The first and last two lines of the ten-line inscription are written outside the tabula. The transcription of the inscription with the new readings is as follows:

$$
\text { ह̌ं }
$$

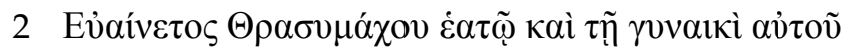

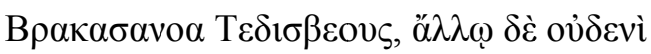

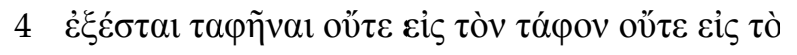

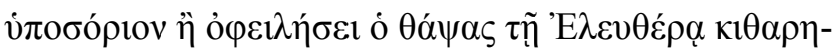

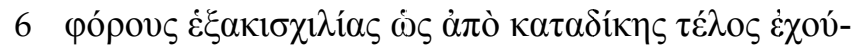

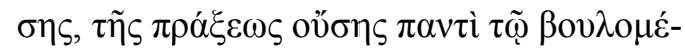

8

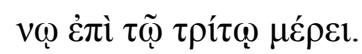

$$
\text { ह̌ं } \pi \mathrm{ol \sigma}[\varepsilon v] \text {. }
$$

In the year 179, on the $11^{\text {th }}$ of the month Audnaios. Euainetos, son of Thrasymachos, (built this tomb) for himself and his wife Brakasanoa, daughter of Tedisbes. Anyone else is not allowed to be buried neither in the sarcophagus nor in the hyposorion, otherwise he who buries the dead person will owe six thousand kitharephoroi to Eleuthera in accordance with the decision taken. After payment of the penalty, the persion denouncing has the right to claim one-third of the money. Theophrastos of Kyaneai made (this tomb). 
L. 1: The first line consists of an era dating with year, month and day. Schweyer (1993,

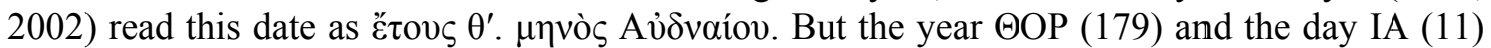
can be read clearly on the stone, see also photograph.

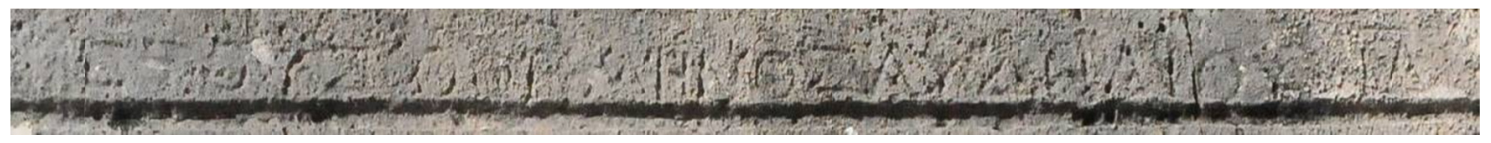

The era of the date $11^{\text {th }}$ Audnaios 179 is probably a new local era dating from the "independance of Lycia from Rhodian domination in 168/7 BC" $(179=\mathrm{AD} 11 / 12)$ or it may be dated from the Sullan era (179=AD 94/5). For details see the following subheading. The month Audnaios in the Macedonian calendar is also used by the Lycians which is equivalent to Martius in the Roman calendar, see in this respect: Bickermann, 1933, 6 and 20; Samuel, 1972, 174. On the lines 61-62 of the customs inscription of Andriake (Takmer, 2006, 50) the names of some

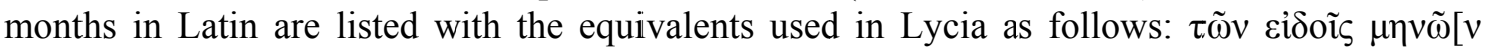

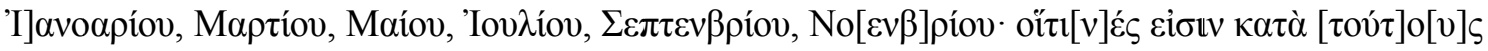

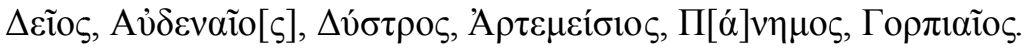

L. 2: Euainetos and his father Thrasymakhos bear names commonly used in Greek. But Euainetos is documented for first time in Lycia in this inscription (Schweyer, 2002, 151).

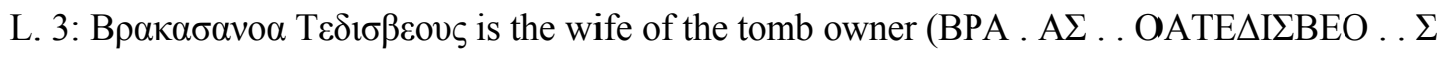
is in the edition of Schweyer, 1993, 41 and Schweyer, 2002, 269 no. 89). Some suggestions about the missing letters were offered by Pleket, SEG 43, 980: "forth letter perhaps $\mathrm{Y}$ or X; seventh letter is triangular, followed by an eta (?) and OA (or $\Lambda$ )OATE $\Delta \mathrm{I} \Sigma \mathrm{BEOIA} \Sigma$ ".

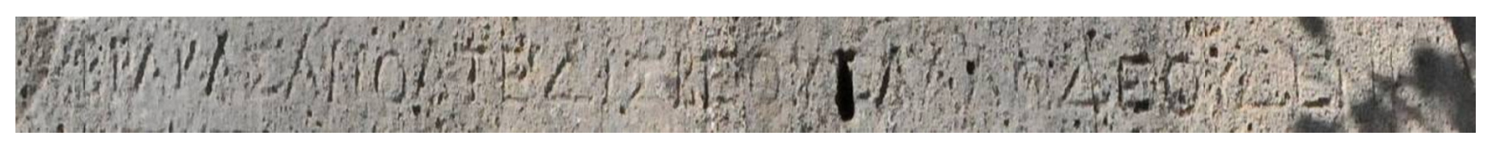

Whereas, these letters BPAKA $\Sigma$ ANOATE $\triangle \mathrm{I} \Sigma \mathrm{BEOY} \Sigma$ are clearly legible. There must be only two personal names here because there is no article and it is not possible to separate the letters of $\Delta \mathrm{I} \Sigma$ as an adverb ( $\delta i \zeta)$. In other words, what must be expected here is a feminine name in the dative case and the name of her father in the genitive case. It is possible to establish the

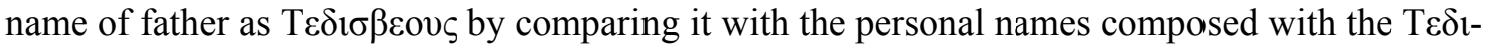

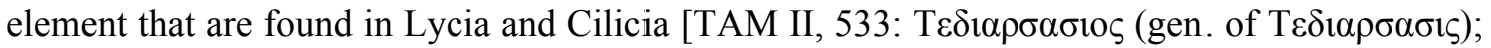

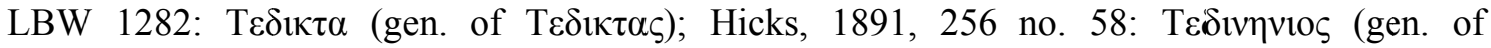

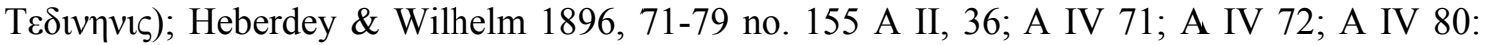

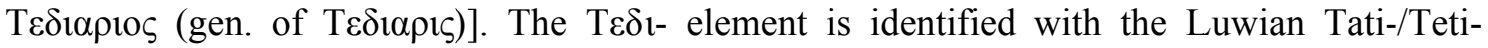

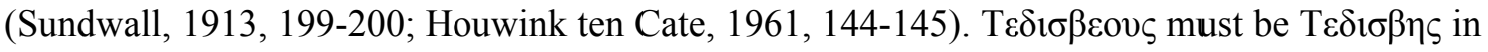
the nominative case (cf. TAM III, 14: M $\alpha v \delta \rho o \beta \eta \varsigma ~ ' E \rho \mu \alpha i ́ o v ~ M \alpha v \delta \rho o \beta \varepsilon o v \varsigma)$. Two examples of the same structure in Lycian: $\Sigma \varepsilon \delta \varepsilon \pi \lambda \eta \varsigma$ (gen. $\Sigma \varepsilon \delta \varepsilon \pi \lambda \varepsilon 0 v \varsigma$ in I Wien, see Zgusta,1964, § 1387-4)

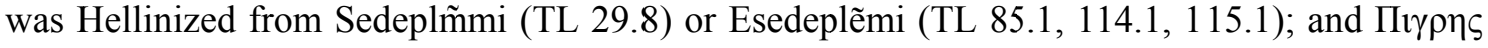

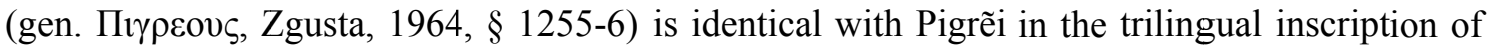
Letoon (N320.15).

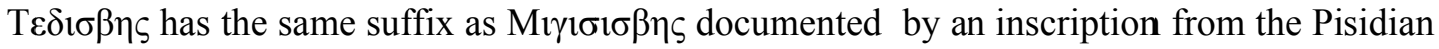

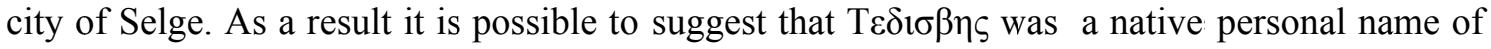

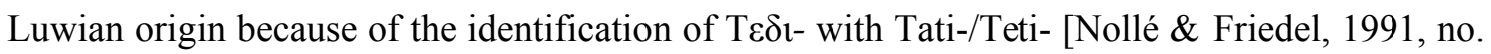

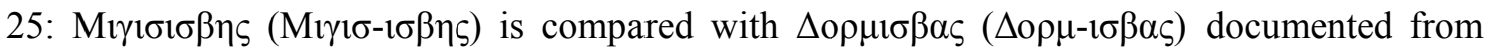
Isauria (Zgusta, 1964, § 300-5) and M $\alpha \sigma v \alpha v i \sigma \beta \alpha \varsigma$ (M $\alpha \sigma v \alpha v-1 \sigma \beta \alpha \varsigma)$ from Termessos (Zgusta,

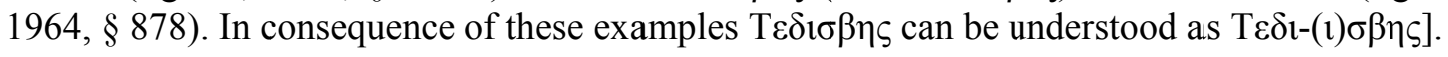

After the identification of the name of the father the remaining BPAKA $\triangle A N O A$ should be

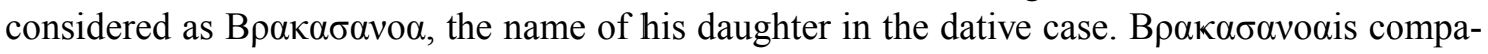


rable with the feminine names with the ending - voo found in Greece and the islands (For a few

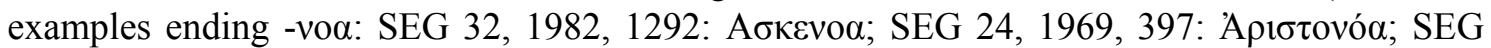

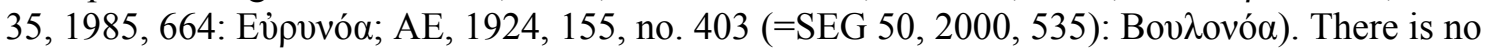

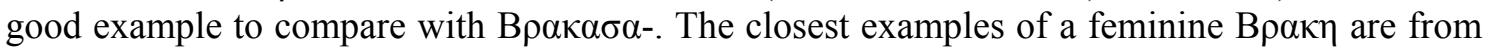
Thrace (LGPN Vol. IV, 74) and a masculine B $\rho \alpha \chi \tilde{\alpha} \varsigma$ from Boiotia (LGPN Vol. IIIB, 89). It seems difficult to say anything definitive about the origin of the name B $\rho \alpha \alpha \sigma \alpha v o \alpha$ but it can be

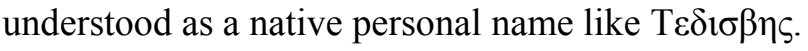

L. 3-6: The penalty formulation of the inscription reports that the violator has to pay six thousand kitharephoroi to Eleuthera as punishment. The coins called kitharephoroi have depicted on the reverse a kithara and are assumed to have been minted by the Lycian League between 167 BC and AD 43 (Regling, 1921, 528-529; Robert, 1951, 150-152; Jameson, 1980, 833 f. and 837 f.; Troxell, 1982, 27). The term is an important indication for the dating of the inscription (see below subheading). Furthermore, the kitharephoroi are documented in six inscriptions from Myra (Diamantaras, 1889, 412-413), Arneai (TAM II, 779) and Istlada (Schuler, 2006, no. 12, 15, 17 and 22).

The Eleuthera mentioned in this inscription is probably the Eleuthera of Trebendai. The Eleuthera Trebendatike ('E $E \varepsilon v \theta \varepsilon \dot{\varepsilon} \rho \alpha$ T $\rho \varepsilon \beta \varepsilon v \delta \alpha \tau 1 \kappa \tilde{)}$ ) is known from a votive inscription from Simena (Heberdey \& Kalinka, 1897, 17 no. 53). There is also a temple dedicated to Eleuthera at

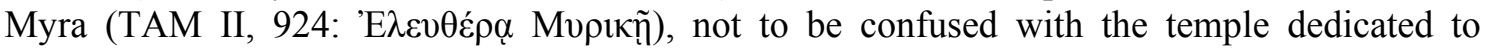
Eleuthera at Trebendai. For those inscriptions concerning Eleuthera at Myra see Petersen \& Luschan, 1889, 45 no. 82; TAM II, 905 XIII C 1. 10, XIV D, XIX A 11. 9-11. It is also known that Trebendai was within a sympoliteia with Myra during the Roman Imperial Period (Petersen

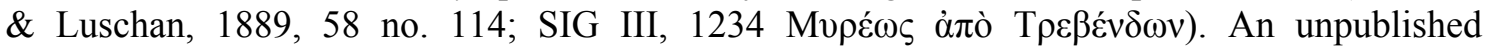
Hellenistic inscription (this inscription was seen in 2010 during a survey carried out under the title of "Likya/Pamfilya Ulaşım Sistemlerinin Epigrafik ve Tarihi Coğrafik Açılardan Araştılması" with the permit of T.C. Kültür ve Turizm Bakanllğ 1 ) consisting of fifteen lines remains at Asarbelen Tepesi lying $500 \mathrm{~m}$ southwest of Muskar/Belören (this inscription is to be seen in the lower left corner of the wall of a late antique building, lying directly to the south of the classical citadel which became a castrum in the Byzantine Period. The inscription is on a spolia block reused in construction of this wall but the block originated from the Hellenistic temple of Eleuthera (Trebendatike), as the last line of this inscription records). An Eleuthera is recorded in the eleventh line of this inscription. Any place name in the inscription is not clearly legible but it is possible to restore the lacuna as T $\rho \varepsilon \beta \varepsilon v \delta \alpha \tau \tilde{\omega} v$ as the ethnicon, which is already known from an inscription carrying the ethnicon of Trebendai in the same form which indicates that it was an independent settlement, from Kyaneai (IGR 3, $704 \mathrm{col}$. I 1.10), in the eighth line of the Asarbelen inscription. If this reading is correct Trebendai can therefore be localised to the Asarbelen Tepesi, Borchhard $(1975,82)$ suggests the settlement of Gürses for localisation of Trebendai. Zimmermann $(1992,115)$ proposed Muskar as alternative to Borchhard's proposal). Taking into consideration that Trebendai was an independent city in the middle $2^{\text {nd }}$ century AD, the settlement on Turant Asarı should be considered as lying within the territory of Trebendai and which therefore raises the question as to the territorial extent of Trebendai. There is a Roman road known as "Gâvur Yolu" coming from the south of Muskar and extending northwest from Muskar in the direction of Çağman and Arneai, which is unfortunately not recorded on the blocks of the Stadiasmus Patarensis (Şahin \& Adak, 2007), as the section which relates to this area is not inscribed, it may originally have carried a painted inscription possibly prior to carving (Şahin \& Adak, 2007, 208 f.). Likewise the road thought to extend from Myra to Arneai is also un-inscribed, as it would be found in this same area of the Stadiasmus Patarensis, but we can predict that this road would have passed through Muskar and that the name Trebendai would therefore have been recorded in this section of the Stadiasmus Patarensis as the first or 
the last station or in the middle with the formulation of " $\delta i \grave{\alpha}+$ station", as Trebendai had an independent territory.

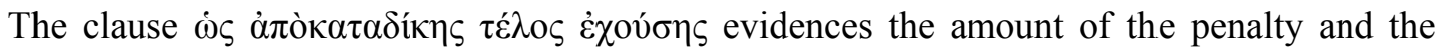
where this legal payment was due. Similar uses of this expression appear in the text of an



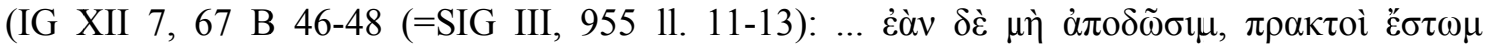

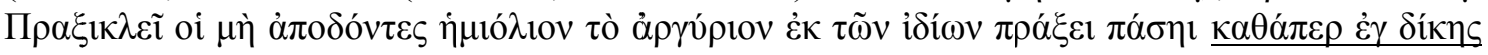

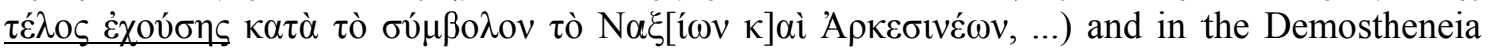

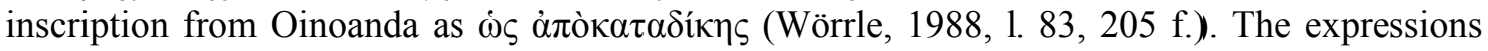

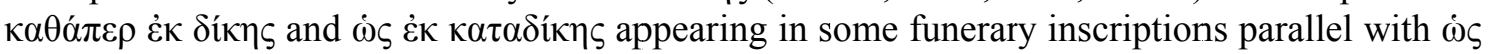

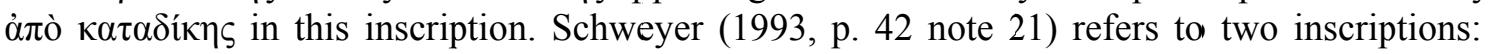
TAM II, 526 (Pinara): ì ḋं

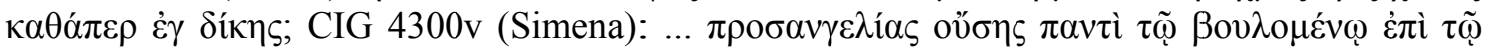

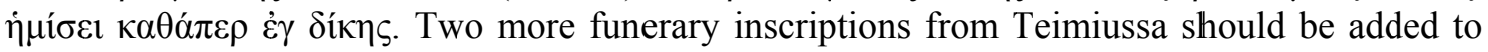

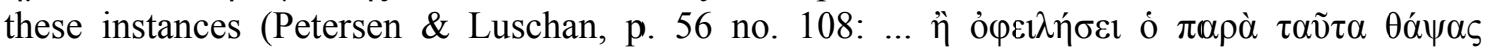

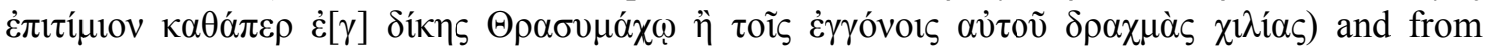

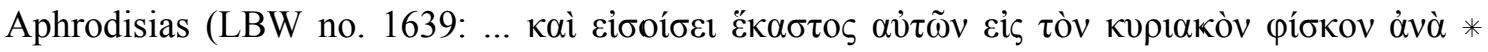

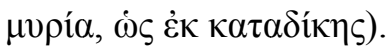

L. 7-8: If any crime is committed against the tomb one-third of the amount of the fine is promised as a reward to the informer.

L. 9-10: The signature of the craftsman who built the grave is placed on this line outside the

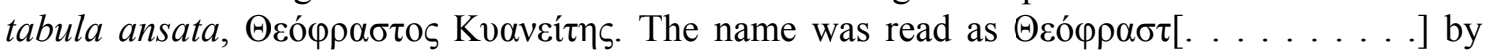
Schweyer (2002, 269 no. 89).

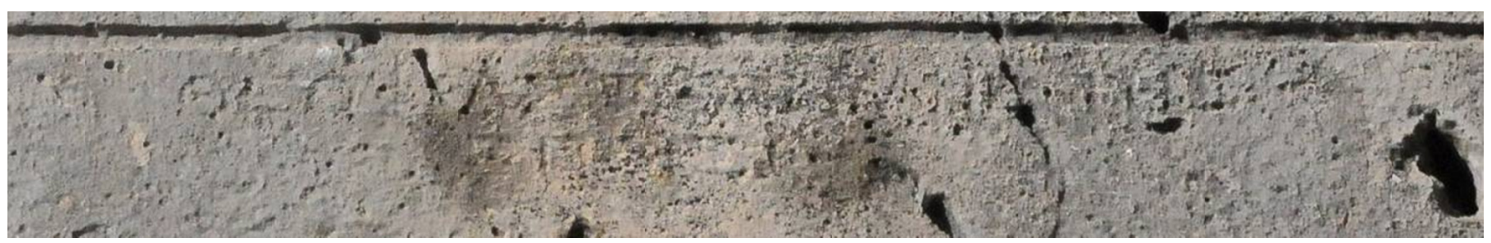

Theophrastos from Kyaneai must have been a famous master in central Lycia at that time but there is today no other known mention of him. On the last line $\ddot{\varepsilon} \pi[0] \imath \sigma[\varepsilon v]=\dot{\varepsilon} \pi \circ$ ín $\sigma \varepsilon v$.

\section{The Dating of the Inscription}

The inscription was not precisely dated in previous publications. It is not clear whether the date in the first line of the inscription was read completely by Harrison $(1979,205)$ who says only "there is a date, which may be Augustan". The inscription was dated to the end of first century $\mathrm{BC}$ or the beginning of first century AD from the style of the letters by Schweyer $(1993,42)$. After the new reading there is now an exact date, $11^{\text {th }}$ Audnaios 179.

But it does not seems possible to say at first glance which year the date $11^{\text {th }}$ Audnaios 179 was reckoned from. This means that it should be considered together with other documents having an era dating. A small number of inscriptions with an era dating have been found in Lycia to date. Eight documents excluding the Turant inscription are known from the cities of Ksanthos, Telmessos, Antiphellos and Oinoanda.

Four of them found at Ksanthos and Telmessos are dated exactly by the Seleucid era. The first is an honorary decree for Themistokles from Ilion recording a speech made in the city of Ksanthos. The decree was dated by the eponym priest Nikanor and by the year 116 with the name of Antiochos III. The year 116 (=196/5 BC) was reckoned from 312/11 BC (Robert, 1983, 154-163 no. 15 [=SEG 33, 1983, 1184]). The other from Ksanthos is a decree of Lyson honored by Ksanthian youth (REG 109, 1996, 2-3). The inscription was dated to the same year as the 
honorary decree for Themistokles.

Another inscription is from Telmessos (Segre, 1938, 190 and Fig. 5; Maier, 1959, 248 no. 76). Only the first two lines of it are available, the rest is missing. On the same stone there is a twenty one-line letter of Eumenes II. There is a year $119(=94 / 93$ BC) in the Seleucid era with the name of Antiochos III. The fourth is a funerary inscription also from Telmessos (TAM II, 41c). The tomb belonged to a person named Aikhmon and the inscription is dated by the year 460 of the Seleucid era and by the eponym Emperor priest Q. Veranius Tlepolemos. The priest is known through an inscription from Kyaneai (IGR III, 705). In the document Q. Veranius Tlepolemos is recorded as emperor priest during the consulate of Scipio Salvidienus Orfitus and Sosius Priscus. The inscription is dated to AD 148/149. So it can be accepted without discussion that the year 460 (=AD 149) as calculated by the Seleucid era (Ruge, 1934, 412; Magie, 1950, 762 note 56; Balland, 1981, 227; Leschhorn, 1993, 42).

The first three inscriptions are official documents and limited to the brief Seleucid dominion over Lycia (197-188 BC). As for the last one, the funerary inscription from Telmessos, the singularity is that the Seleucid era appears again in the middle of second century AD which is interesting. Leschhorn (1993, 42) interprets this occurrence after a long time interval as indicating the revival of the traditional consciousness of the city and of its historical memory (for a similar comment see Tietz, 2001, 310-311).

The remaining four documents dated by era are very ambiguous. One of them is an Hellenistic inscription on the tomb of a person called Philtes at Telmessos (Fellows, 1841, 382; CIG 4199; TAM II, 42). From the inscription we learn that the tomb was given to him by the polis. There is a date ("̌̃ovs $\xi^{\prime} \mu \eta v$ ò $\Lambda$ óov $\alpha^{\prime}$ "1 $1^{\text {st }}$ Loos 60 ") in the first line of this short inscription. Various suggestions have been proposed for the era of this date, that it was Egyptian (Kalinka's opinion, see commentary of TAM II, 42; Ruge, 1934, 412; Magie, 1950, 762 note 56) or Seleucid (Wilhelm's opinion, see commentary of TAM II, 42; Leschhorn, 1993, 27-28) or was a local era dating from the freedom Lycia obtained from Rhodian dominion (Fellows, 1841, 382) or it was Sullan (Fellows, 1841, 382; in commentary of CIG 4199; Tietz, 2001, 311 note 75).

The other document is a recently published Hellenistic inscription comprising a treaty between "the Termessians nearby Oinoanda" and the Lycian League (Rousset, 2010). The text is dated by the name of the eponymous priests of the treaty parties. Further, the date $\left(18^{\text {th }}\right.$ Daseios 34) of a local era was added for the Termessians. The era of the year 34 is unknown and has appeared for the first time in Lycia. According to the editor of the inscription (Rousset, 2010, 20-23), the begining of this era is dated from one of two possiblities: either from the foundation of Termessos or from the reglement of Apameia (188 BC). Rousset dates this inscription between the years 160-150 BC.

Another funerary inscription having an era dating was found at Antiphellos (CIG 4300e in addenda; LBW 1274). The tomb was built by Dorothes, a citizen of Antiphellos for himself and his family. At the end of the inscription is recorded the year 121 (हैं $\left.\varepsilon 1 \rho \kappa \alpha^{\prime}\right)$. Previously it was thought 121 related to the Sullan era (CIG 4300e) and consequently 121 corresponds to AD 36/7. But Leschhorn has proposed that this inscription should be dated to the period after AD 43 by indicating the personal name Claudius given in this inscription. As a result, for the begining era of the year 121 Leschhorn (1993, 414-415 and 541) suggests the year AD 43 was a new local era dating from "the foundation of the province of Lycia" by the Emperor Claudius in AD 43. Merkelbach (2000, 121 and Merkelbach \& Stauber, 2002, 32) accepts the year AD 43 as beginning of an era on the comments about of the $\pi \rho$ ò $\dot{\tau} \tilde{\omega} \nu \rho \kappa \theta$ in the inscription from Sidyma (TAM II, 174). But the $\pi \rho \grave{~} \dot{\tau} \tilde{\tilde{\omega}} \nu \rho \kappa \theta$ cannot be seen as a date reckoned by an era, cf. Takmer 2010, 113 no. 159.

A silver plaque with an inscription which was found near Oinoanda (Jacobsthal \& Jones, 
1940, 16-31; Robert, 1983, 578-579; SEG 33, 1983, 1179; Leschhorn, 1993, 359, 414 ) can be added to these inscriptions. This plaque was made on behalf of the Muangla demos near Oinoanda and Kibyra and was dedicated to Zeus. The inscription on the plaque was dated to year 115 of an era. Jacobsthal \& Jones (1940, 27-29) thought of this era in connection with Cibyra and suggested two possiblities for the beginning of this era; either $85 \mathrm{BC}$ or AD 25 employed as the start of an era by the city of Cibyra.

All of these remain arguable, nevertheless as is indicated by the opinions expressed concerning these inscriptions, it seems most probable that some local eras were employed by the Lycians.

As for the Turant inscription, if one thinks the Seleucid era was employed, then the year 179 corresponds to $133 / 32 \mathrm{BC}$. However, given the form of the letters employed in this inscription it is impossible to date this inscription to $133 / 32 \mathrm{BC}$.

If the date of the inscription is calculated according to the Sullan era, 179 gives AD 94/5. This year corresponding to the end of the first century AD is not too far from the date of the inscription based upon the form of the letters employed. However this dating needs to be supported from the evidence concerning the use of the kitharephoroi, given in the penalty payment recorded in this inscription. It is assumed that kitharephoroi were minted when the Lycian League was independant between $167 \mathrm{BC}$ and $\mathrm{AD}$ 43. It is possible to consider the kitharephoroi might have been in circulation after $\mathrm{AD} 43$ although whether kitharephoroi would have been specified by name after AD 43 seems questionable. A declaration in the customs inscription of Andriake dating from Nero's reign provides a good example indicating currency previously circulating in Lycia remained in circulation after the formation of the province of

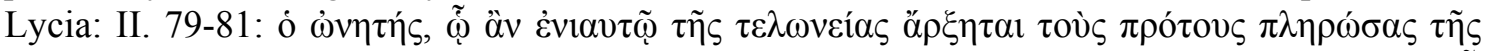

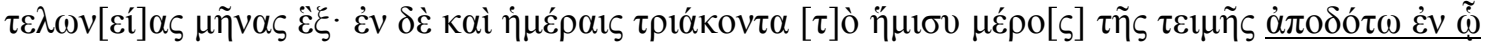

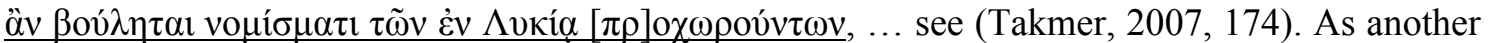
piece of evidence it can be understood that the coins carrying a kithara minted in the province of Lycia between the years AD 95-99 in the reigns of Domitianus, Nerva and Traianus might have been termed kitharephoroi (SNG 4265: Domitianus, with kithara, the date: ETOY $\Sigma$ I $\Delta$ ҮПАТОY IZ (=AD 95); SNG 4266: Nerva, with two lyres, the date: YПATOY TPITOY (=AD 97); SNG 4267: Traianus, with two lyres, the date: $\triangle$ HM Е $\Xi$ YПАТ В (=AD 98-99). There is no any date on the coins with kithara minted in the name of Claudius (SNG 4263, 4264). On the basis of the interpretation made by Robert (1951, 151: "On a reconnu dans ces "citharephores" les monnaies de la Confédération Lycienne ayant au revers une cithare; il peut s'agir, suivant la date de l'inscription, soit des monnaies autonomie de la Lycie jusqu'à 43 de notre ère, soit des monnaies au nom de Claude, de Domitian, de Nerva et de Trajan ayant pour type du revers une ou deux cithares"), concerning the kitharephoroi in order to date the Myra inscription (Diamantaras, 1889, 412-413), the coins with kithara struck during the reigns of the emperors mentioned above may also be named as kitharephoroi. Within the framework of these two possibilities, the Turant inscription may be dated to AD 95 from 179 in the Sullan era. Nevertheless this dating remains doubtful and should not be regarded as conclusive. As only six inscriptions recording kitharephoroi employed to describe a monetary unit for penalty payments have been found to date and probably all of them are to be dated to the Hellenistic period. Four of them are found at Istlada, for the document and the dates see (Schuler, 2006, 395-451, nos. 12, 15, 17 and 22). The other inscription is from Arneai; the style of the letters seen on the detailed drawing of maiscul clearly reflectthe late Hellenistic period (TAM II, 779). The dating of the Myra inscription (Diamantaras, 1889, 412-413) interpreted by Robert (see note 18) is not certain. It also probably belonged to the period before Emperor Claudius.

It is impossible to consider any era later than that of Sulla to date the inscription due both to the style of the letters and because of the word kitharephoroi. When the approximately datings around the time of Augustus - proposed by Harrison and Schweyer are taken into consideration, 
the year 179 goes back to the first half of the second century BC. During this period the most important year is 168/167 BC when Lycia regained independence from Rhodian control, which would mark the beginning of an Lycian era. This thought was previously expressed by Fellows $(1841,382)$ in his comments concerning the inscription of Telmessos (TAM II, 42), that the year of freedom from Rhodian domination might mark the beginning of a new era. In this context the numbers ranging from 1 to $33(\mathrm{~A}-\Lambda \Gamma)$ that appear on the coins of the Carian city of Alabanda were used to mark the years dating from the era of the liberation of this city from Rhodian domination, that is $168 / 167 \mathrm{BC}$ (for the details and literature concerning this see Leschhorn, 1993, 201-204, 487). If this year is assumed to mark the beginning of an era, the year 179 corresponds to the year AD 11/12 which agrees with the dating from the typology of sarcophagus and style of the letters forming the Turant inscription. Although any document establishing the existence of this "the freedom era" has yet to be found in Lycia, it is not beyond the realms of possibility that the year $167 \mathrm{BC}$ might well have marked the beginning of an era.

Looking collectively at the existing inscriptions dated by era in Lycia, four of them are dated exactly by the Seleucid era, while a few other inscriptions remain disputable. Although few known documents to date attest to it, it seems most probably that some local eras were employed by the Lycians. Finally, for the era of dating employed on the Turant inscription two distinct possibilities can be proposed: the firstly, that the local era dates from the acquisition of independence by Lycia from Rhodian domination which seems the more preferable, the second having a much diminished possibility is dating from the Sullan era.

\section{REFERENCES}

Balland, A. (1981). Inscripions d'époque impériale du Létôon (Fouilles de Xanthos VII). Paris.

Behrwald, R. (2000). Der Lykische Bund. Untersuchungen zu Geschichte und Verfassung (Antiquitas, Reihe 1, Band 48). Bonn.

Bickermann, E. (1933). Chronologie (Einleitung in die Altertumswissenschaft, III. Band, 5. Bulletin). Leipzig, Berlin.

Borchhardt, J. (1975). Die Ruinen von Gürses. In J. Borchhardt (Ed.), Myra. Eine lykische Metropole in antiker und byzantinischer Zeit (81-86) (Istanbuler Forschungen 30). Berlin.

CIG. Corpus Inscriptionum Graecarum.

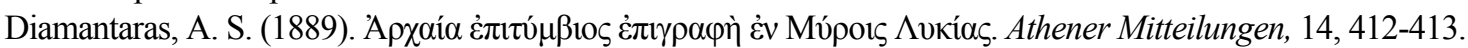

Fellows, C. (1841). An Account of Discoveries in Lycia. London.

Harrison, M. (1979). Lycian Survey 1978. In R. Naumann et al., Recent Archaeological Research in Turkey, Anatolian Studies, 29, 181-210.

Harrison, M. (2001). Mountain and Plan. From the Lycian Coast to the Phrygian Plateau in the Late Roman and Early Byzantine Period. Ann Arbor.

Heberdey, R., \& Wilhelm, A. (1896). Reisen in Kilikien (Denkschrift Österreichische Akademie der Wissenschaften, Philosophisch-historische Klasse 44). Vienna.

Heberdey, R., \& Kalinka, E. (1897). Bericht über zwei Reisen im südwestlichen Kleinasien (Östereichische Akademie der Wissenschaften Denkschriften 45). Vienna.

Hellenkemper, H., \& Hild, F. (2004). Tabula Imperii Byzantini 8: Lykien und Pamphylien (Denkschrift Österreichische Akademie der Wissenschaften, Philosophisch-historische Klasse 320). Vienna.

Hicks, E. L. (1891). Inscriptions from Western Cilicia. Journal of Hellenic Studies, 12, 225-273.

Houwink ten Cate, P. H. J. (1961). The Luwian Population Groups of Lycia and Cilicia Aspera during the Hellenistic Period. Leiden.

IG. Inscriptiones Graecae.

IGR. Inscriptiones Graecae ad Res Romanas Pertinentes.

Jacobsthal, P., \& Jones, A. H. M. (1940). A Silver Find from South-West Asia Minor. Journal of Roman Studies 30, 16-31.

Jameson, S. (1980). The Lycian League: Some Problems in its Administration. Aufstieg und Niedergang der römischen Welt II.7.2, 832-855. 
LBW Le Bas, P., \& Waddington, W. H. (1972). Inscriptions Grecques et Latines recuellies en Asie Mineure I-II. New York (The first edition Paris 1870).

Leschhorn, W. (1993). Antike Ären. Zeitrechnung, Politik und Geschichte im Schwarzmeerraum und in Kleinasien nördlich des Tauros (Historia 81). Stuttgart.

LGPN A Lexicon of Greek Personal Names. Oxford.

Magie, D. (1950). Roman Rule in Asia Minor, I-II. Princeton, New Jersey.

Maier, F. G. (1959). Griechische Mauerbauinschriften I: Texte und Kommentare (Vestigia, Beiträge zur Alten Geschichte, Band I). Heidelberg.

Mellink, M. J. (1979). Archaeology in Asia Minor. American Journal of Archaeology, 83, 331-344.

Merkelbach, R. (2000). Der Glanz der Städte Lykiens. Epigraphica Anatolica, 32, 115-126.

Merkelbach, R., \& Stauber, J. (2002). Steinepigramme aus dem griechischen Osten, Band 4: Die Südküste Kleinasiens, Syrien und Palaestina. Munich, Leipzig.

Nollé, J., \& Friedel, S. (1991). Die Inschriften von Selge (Inschriften griechischer Städte aus Kleinasien 37). Bonn.

Petersen, E., \& von Luschan, F. (1889). Reisen in Lykien, Milyas und Kibyratis. Reisen im südwestlichen Kleinasien II. Vienna.

Regling, (1921). кıө

Robert, L. (1951). Études de numismatique grecque. Paris.

Robert, L. (1983). Documents d'Asie Mineure. Bulletin de Correspondance Hellénique, 107/1, 497-599.

Robert, J., \& L. (1983). Foulles d'Amyzon en Carie I: Exploration, Histoire, Monnaies et Inscriptions. Paris.

Rousset, D. (2010). De Lycie en Cabalide: la convention entre les Lyciens et Termessos près d'Oinoanda. (Fouilles de Xanthos X). Geneva.

Ruge, W. (1934). Telmessos (2). RE $V A_{2}, 410-415$.

REG Revue des Etudes Grecques (Paris).

Samuel, A. E. (1972). Greek and Roman Chronology: Calendars and Years in Classical Antiquity. Munich.

Schuler, C. (2006). Inschriften aus dem Territorium von Myra in Lykien: Istlada. Chiron 36, 395-451.

Schweyer, A. V. (1993). Essai de definition des $\chi \omega ́ p \alpha \imath$ de Telmessos et de Myra. In J. Borchhardt - G. Dobesch (Ed.), Akten des II. Internationalen Lykien-Symposions Wien, 6.-12. Mai 1990. Ergänzungsbände zu den Tituli Asiae Minoris, 18, Band II (39-42 ). Vienna.

Schweyer, A. V. (2002). Les Lyciens et la mort. Une etude d'histoire sosiale (Varia Anatolica 14). Paris.

SEG Supplementum Epigraphicum Graecum.

Segre, M. (1938). Iscrizioni di Licia. Clara Rhodos IX, 179-208.

SIG Sylloge Inscriptionum Graecarum.

Sundwall, J. (1913). Die einheimischen Namen der Lykier nebst einem Verzeichnisse kleinasiatischer Namenstämme (Klio, Supplement 11). Leipzig.

Şahin, S., \& Adak, M. (2007). Stadiasmus Patarensis. Itinera Romana Provinciae Lyciae (Monographien zur Gephyra, Band 1).

Takmer, B. (2006). Lex Portorii Provinciae Lyciae: Lykia Eyaleti’nin Gümrük Yasası (Unpublished doctoral dissertation). University of Akdeniz, Antalya.

Takmer, B. (2007). Lex Portorii Provinciae Lyciae. Ein Vorbericht über die Zollinschrift aus Andriake aus neronischer Zeit. Gephyra 4, 165-188.

Takmer, B. (2010). Stadiasmus Patarensis için Parerga 2: Sidyma I. Yeni Yazıtlarla Birlikte Yerleşim Tarihçesi. Gephyra 7, 95-136

TAM Tituli Asiae Minoris.

Tietz, W. (2001). Der Golf von Fethiye. Politische, ethnische und kulturelle Strukturen einer Grenzregion vom Beginn der nachweisbaren Besiedlung bis in die römische Kaiserzeit (Antiquitas, Reiche 1, Abhandlungen zur Alten Geschichte 50). Bonn.

Troxell, H. A.(1982). The Coinage of the Lycian League (Numismatic Notes and Monographs 162). New York.

Wörrle, M. (1988). Stadt und Fest im kaiserzeitlichen Kleinasien: Studien zu einer agonistischen Stiftung aus Oinoanda (Vestigia 39). Munich.

Zgusta, L. (1964). Kleinasiatische Personennamen. Prague.

Zimmermann, M. (1992). Untersuchungen zur historischen Landeskunde Zentrallykiens (Antiquitas, Reihe 1, Abhandlungen zur Alten Geschichte 42). Bonn. 